\section{Nauplius}

The Journal of The

Brazilian Crustacean Society

e-ISSN 2358-2936

www.scielo.br/nau www.crustacea.org.br
This article is part of the special series offered by the Brazilian Crustacean Society

in honor to Ludwig Buckup in recognition of

his dedication and contributions to the development of Carcinology

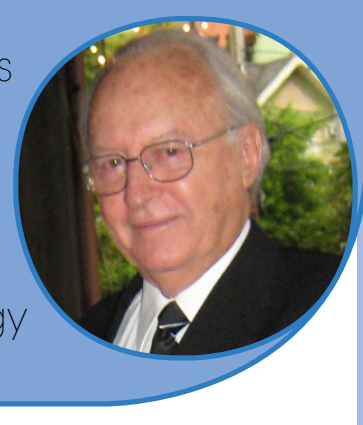

Original Article

\title{
Growth of the burrowing crayfish Parastacus nicoleti (Philippi, 1882) (Crustacea, Decapoda, Parastacidae)
}

\author{
Miguel Yáñez-Alvarado' (D) orcid.org/0000-0001-5483-3428 \\ Erich Rudolph-Latorre ${ }^{2}$ (D) orcid.org/0000-0001-9397-5976 \\ Jessica Orellana-Olave ${ }^{1}$ (D) orcid.org/0000-0003-1 189-4751
}
1 Departamento de Estadística, Universidad del Bío-Bío, Casilla 5-C, Concepción, Chile
2 Departamento de Ciencias Biológicas y Biodiversidad, Universidad de Los Lagos, Casilla 933, Osorno, Chile
ZOOBANK http://zoobank.org/urn:lsid:zoobank.org:pub:BC001F86-5484-492E- BD02-02877149C161

\section{ABstract}

We examined the individual growth of the burrowing crayfish Parastacus nicoleti (Philippi, 1882) based on a sample of 1,425 specimens. Individuals were collected monthly from November 1981 to December 1982, in the marshy wetlands of the "Pangal" homestead in Reumen, southern Chile. The Cephalothorax Length (CL) and Body Weight (BW) were recorded for all specimens. The asymptotic length parameters $\left(L_{\infty}\right)$ and the growth coefficient $(\mathrm{k})$ were established using the Gulland and Holt method (1959). The $t_{0}$ parameter was obtained through the inverse von Bertalanffy equation and the length-weight relationship was determined according to the equation proposed by Ricker (1975). The asymptotic size and weight were $45.754 \mathrm{~mm}$ and $18.50 \mathrm{~g}$, respectively. The growth constant was $0.703 /$ year. Estimated longevity was 4.32 years. We concluded that $P$. nicolet $i$ is a relatively small species with poor growth indicators for size and weight and, consequently, is not an attractive species for commercial aquaculture purposes.

\section{Guest Editors}

Alessandra Angélica de Pádua Bueno and Sandro Santos

\section{KEY WORDS}

Longevity, freshwater crayfish, growth parameters, asymptotic size and weight, southern Chile. 


\section{INTRODUCTION}

The burrowing crayfish Parastacus nicoleti (Philippi, 1882) inhabits underground waters from semimarshland areas of Chile (Rudolph, 2010; 2013). Its distribution ranges from the locality of Gorbea ( $39^{\circ} 05^{\prime} \mathrm{S} 72^{\circ} 38^{\prime} \mathrm{W}$ ) (Araucanía Region) to the Chaqueihua River (41 $26^{\prime} \mathrm{S} 73^{\circ} 06^{\prime} \mathrm{W}$ ) (Los Lagos Region) in southern Chile (Rudolph, 2010; 2013). It burrows galleries of variable morphology in these terrains, which can reach depths of up to $2.0 \mathrm{~m}$ during the summer (Kilian, 1959). This species plays an important ecological role, as a keystone trophic regulator and ecological engineers in the marshy wetlands of the Cordillera de la Costa of the Los Rios and Los Lagos Regions (Rudolph and Almerão, 2015). Nevertheless, biological knowledge about this species is still scarce and fragmented. The few studies carried out have concentrated mainly on describing the burrowing behavior (Kilian, 1959), embryonic and early postembryonic development (Rudolph and Zapata, 1986), sexual system (Rudolph, 1995), burrow structure and associated physicochemical parameters (Rudolph, 1997). In spite of this lack of knowledge, some authors have classified this species according to the conservation categories established by the IUCN (2012) considering, for this purpose, the degradation of its natural environment due to anthropic action, as the main threat to its conservation. Thus, Bahamonde et al. (1998) and Rudolph and Crandall $(2005 ; 2007)$ classified it as Vulnerable (VU); Buckup (2010) and Almerão et al. (2015) as Data deficient (DD); and the Ministerio del Medio Ambiente de Chile (MMA, 2013) (Ministry of the Environment), as Least Concern (LC). These different categorizations reveal the need for additional studies, especially with regard to the population ecology and reproductive biology in order to achieve a more precise evaluation. In this way, it will be facilitated the progress in terms of implementing efficient of conservation measures.

Knowledge about the individual growth of a species is of transcendental importance to estimate population size more accurately (Arreguín et al., 1991). Furthermore, it is indispensable when determining the commercial culture viability of a given species (Lobão et al., 1987), and fundamental to the design of opportune and efficient management, protection and conservation strategies (Rodríguez and Bahamonde, 1986; Wright-
López et al., 2009). Taking this into account, the aim of study is to characterize the individual growth of $P$. nicoleti, based on measurements of length and weight, using the biological growth model of von Bertalanffy (1938).

\section{Materials and Methods}

\section{Sampling}

The $P$. nicoleti specimens were collected with a manual suction pump applied directly over the entrances to their burrows in the marshy wetlands of the "Pangal" homestead (39 $\left.59^{\prime} \mathrm{S} 72^{\circ} 52^{\prime} \mathrm{W}\right)$, located in the locality of Reumén, province of Valdivia, Los Ríos region, southern Chile. Monthly samples were taken from November 1981 to December 1982, at 14 different points, one for each sampling. The animals captured were deposited in plastic bags and fixed in $70 \%$ ethanol for subsequent identification and analysis in the laboratory, using the morphological characters described by Ribeiro and Araujo (2017). The cephalothorax length (CL) of each specimen was measured in millimeters, from the distal end of the rostrum to the posterior margin of the carapace, and wet body weight (W) was recorded in grams, after leaving specimens to drain for three minutes on filter paper. In both types of recording, the sex of the individuals was indistinguishable, since $P$. nicoleti is a partial protandric hermaphrodite species with six gonopore patterns (Rudolph, 1995), making it difficult to distinguish the sex of its representatives externally.

\section{Length-weight relationship}

The length-weight relationship was determined applying the equation proposed by Ricker (1975): $W$ $=a L^{b}$ where $W$ is weight in grams, $L$ is length of the cephalothorax in millimeters and $b$ is the allometric growth constant. The parameters $a$ and $b$ were estimated by the weighted least squares (WLS) method using the SPSS v. 19 program, prior to linearization of the model through logarithmic transformation.

\section{Growth parameters}

Estimation of growth was based on analysis of the frequency distribution of cephalothorax length, identifying age groups using the Bhattacharyas method (Bhattacharya, 1976) of the FiSATT II program (Gayanilo et al., 2005). First, the growth coefficient $k$ 
and the asymptotic length $\left(L_{\infty}\right)$ were estimated using the Gulland and Holt (1959) method, that served as a basis for estimating theoretical age $t_{\alpha}$, according to the von Bertalanffy (1938) equation as follows:

$-\ln \left(1-\frac{L_{t}}{L_{\infty}}\right)=-k t_{0}+k t$. The Taylor equation (1958) was used for calculation of longevity:

$t_{\max }=t_{0}+\frac{3}{k}$, where $t_{\text {max }}$ is the maximum age or time required to reach $95 \%$ of the asymptotic length $\left(L_{\infty}\right)$. The asymptotic weight is estimated according to the expression proposed by Csirke (1980): $W_{\infty}=a L_{\infty}^{b}$ where $W_{\infty}$ is the asymptotic weight or average maximum weight.

Once the $L_{\infty}, W_{\infty}, k$ and $t_{0}$ are estimated, the growth curves in length and in weight were determined, adjusted to the von Bertalanffy model (1938), according to the models $L_{t}=L_{\infty}\left(1-e^{-k\left(t-t_{0}\right)}\right)$ and $W_{t}=W_{\infty}\left(1-e^{-k\left(t-t_{0}\right)}\right)^{b}$, respectively.

\section{ResULTS}

A total of 1,425 individuals were collected; the CL of 1,178 specimens ranged from 2.4 to $46.0 \mathrm{~mm}$ (247 specimens were discarded because of fractures in their carapace) and the body weight of all 1,425 individuals ranged from 0.01 to $20.07 \mathrm{~g}$ (Tabs. 1, 2). In Tab. 1 , we observe that the relative dispersions in size of the specimens caught fall within a range of 0.278 to 0.421 , where the lowest and highest relative dispersion is produced in those specimens caught in November 1981 and January 1982, respectively. On the other hand, in Tab. 2, the weights recorded during the study period exhibit high relative variability, presenting values that differ significantly from the averages. The asymptotic length estimated by the growth curve $(45.75 \mathrm{~mm})$ was very similar to the CL of the largest specimen measured $(46.0 \mathrm{~mm})$.

\section{Length-weight relationship}

The size-weight relationship can be observed in Fig. 1, showing greater concentration in the lower values. The intercept of the linearized model is statistically significant for this curve $(|\mathrm{t}|=71.17 ; p<0.01)$, as is the slope of the model $(|\mathrm{t}|=76.51 ; p<0.01)$; thus, the length-weight relationship is established as
$W=0.00021 L^{2.97}$. The value of the slope $(b=2.97)$ indicates an approximately isometric growth (Hartnoll, 1982), denoting that, as the individuals grow, their body proportions are maintained.

\section{Growth parameters}

The asymptotic length and growth coefficient estimated according to the Gulland and Holt (1959) method were $L_{\infty}=45.754 \mathrm{~mm}$ and $k=0.703$ /year, respectively. Subsequently the theoretical age obtained employing the von Bertalanffy method was $t_{\mathrm{o}}=0.055$ years. The longevity or maximum age $\left(t_{\text {max }}\right)$ calculated was 4.32 years. The asymptotic weight $\left(W_{\infty}\right)$ was obtained using the estimated parameters of the sizeweight relationship and the estimated asymptotic length $\left(L_{\infty}\right)$, obtaining the value of $W_{\infty}=18.50 \mathrm{grs}$.

The estimated models of size and weight were, respectively, $L_{t}=45.754\left(1-e^{-0.703(t-0.055)}\right) \quad$ and $W_{t}=18.50\left(1-e^{-0.703(t-0.055)}\right)^{2.97}$.

\section{Discussion}

The estimated length-weight proportion indicated that growth of $P$. nicolet is isometric $(b \approx 3.0)$. The same pattern was found for Parastacus pugnax (Poeppig, 1835) ( $b \approx 3.0)$ (Ibarra and Arana, 2012) and for males of Samastacus spinifrons (Philippi, 1882) $(b=3.0)$ (Bocic et al., 1988). However, females of S. spinifrons showed negative allometry in growth (Bocic et al., 1998).

The increase in length $(\mathrm{K})$ estimated for P. nicoleti was higher than in other astacid and parastacid crayfishes from cold waters, except for Austropotamobius torrentium (Schrank, 1803) (see Tab. 3). In fact, this parameter is only comparable to the increase in length calculated for a species inhabiting warmer waters which has significant commercial importance, as the North American cambarid Procambarus clarkii (Girard, 1852) (Anastacio and Marques, 1995; Streissl and Hödl, 2002; Chiesa et al., 2006; Scalici and Gherardi, 2007). However, the value of the asymptotic cephalothorax length for $P$. nicoleti is below the value estimated for all the species of crayfish whose individual growth parameters are presented in Tab. 3, with the exception of Parastacus defossus Faxon, 1898 (Noro and Buckup, 2009) and P. brasiliensis 
Table 1. Cephalotorax length (CL) monthly average (mm) of the Parastacus nicoleti specimens.

\begin{tabular}{lcccccccc}
\hline \multicolumn{1}{c}{ Month } & Year & $\mathrm{n}$ & Min & - & Max & Mean & SD & CV \\
\hline November & 1981 & 52 & 13.7 & - & 40.0 & 21.917 & 6.0868 & 0.278 \\
December & 1981 & 70 & 2.4 & - & 41.4 & 19.970 & 5.5975 & 0.280 \\
January & 1982 & 55 & 8.2 & - & 40.0 & 19.873 & 8.3750 & 0.421 \\
February & 1982 & 32 & 10.0 & - & 41.7 & 18.750 & 6.6005 & 0.352 \\
March & 1982 & 56 & 12.4 & - & 42.0 & 22.871 & 6.8950 & 0.301 \\
April & 1982 & 77 & 13.3 & - & 43.8 & 23.047 & 6.4920 & 0.282 \\
May & 1982 & 112 & 10.0 & - & 46.0 & 22.760 & 6.9150 & 0.304 \\
June & 1982 & 101 & 12.2 & - & 45.7 & 24.526 & 8.0336 & 0.328 \\
July & 1982 & 127 & 10.5 & - & 42.8 & 20.457 & 7.4319 & 0.363 \\
August & 1982 & 102 & 10.8 & - & 43.0 & 21.951 & 8.4211 & 0.384 \\
September & 1982 & 101 & 12.9 & - & 43.3 & 24.988 & 9.3646 & 0.375 \\
October & 1982 & 87 & 12.4 & - & 40.8 & 25.982 & 7.8921 & 0.304 \\
November & 1982 & 146 & 8.7 & - & 40.0 & 20.573 & 7.0924 & 0.345 \\
December & 1982 & 61 & 10.4 & - & 40.2 & 20.782 & 8.1874 & 0.394 \\
\hline Global & & 1,179 & 2.4 & - & 46.0 & 22.226 & 7.7610 & 0.349 \\
\hline
\end{tabular}

$\mathrm{SD}=$ stardard deviation

$\mathrm{CV}=$ coefficient of variation

Table 2. Average monthly weight (g) of the Parastacus nicoleti specimens.

\begin{tabular}{lccccccccc}
\hline \multicolumn{1}{c}{ Month } & Year & $\mathrm{n}$ & Min & - & Max & Mean & SD & CV \\
\hline November & 1981 & 65 & 0.05 & - & 14.75 & 2.395 & 2.8008 & $>1$ \\
December & 1981 & 116 & 0.03 & - & 14.30 & 1.465 & 2.0118 & $>18$ \\
January & 1982 & 74 & 0.05 & - & 14.80 & 1.648 & 2.6334 & $>1$ \\
February & 1982 & 33 & 0.19 & - & 15.48 & 2.000 & 2.8276 & $>1$ \\
March & 1982 & 78 & 0.04 & - & 16.73 & 2.218 & 3.1371 & $>1$ \\
April & 1982 & 89 & 0.04 & - & 17.03 & 2.672 & 3.3536 & $>1$ \\
May & 1982 & 120 & 0.05 & - & 17.38 & 2.911 & 2.9965 & $>1$ \\
June & 1982 & 108 & 0.02 & - & 20.07 & 3.485 & 3.7599 & $>1$ \\
July & 1982 & 136 & 0.05 & - & 15.62 & 2.373 & 2.8642 & $>1$ \\
August & 1982 & 138 & 0.01 & - & 16.33 & 2.587 & 3.4905 & $>1$ \\
September & 1982 & 143 & 0.01 & - & 18.84 & 3.265 & 4.6800 & $>1$ \\
October & 1982 & 83 & 0.39 & - & 15.15 & 5.019 & 4.0044 & 0.798 \\
November & 1982 & 174 & 0.05 & - & 12.86 & 2.055 & 2.7584 & $>1$ \\
December & 1982 & 68 & 0.14 & - & 11.57 & 2.270 & 2.9365 & $>1$ \\
Global & & 1,425 & 0.01 & - & 20.07 & 2.614 & 3.3633 & $>1$ \\
\hline
\end{tabular}

$\mathrm{SD}=$ stardard deviation

$\mathrm{CV}=$ coefficient of variation

(von Martens, 1869) (Fries, 1984). These data suggest that $P$. nicoleti would be a relatively small species, with a rapid increase in length, at least prior to reaching between 20 and $30 \mathrm{~mm} \mathrm{CL}$ (Fig. 2). Within this size range, the reproductive processes of $P$. nicoleti females would begin and, consequently, energy is diverted towards these processes and somatic growth slows down. According to Rudolph (1995), the puberty moult in $P$. nicoleti would occur between 20 and $25 \mathrm{~mm} \mathrm{CL}$, sizes that would be reached - according to the growth model of this species - after a period of between 318.6 and 430.6 days. Furthermore, the smallest size recorded for an ovigerous female was 29.2 mm CL (Rudolph, 1995).

Although the size and commercial weight of crayfish species that are successfully cultured worldwide vary considerably, in general, for a species to be considered attractive for human consumption, it must present a minimum size of $9 \mathrm{~cm}$ total length and weigh around $25 \mathrm{~g}$ (Huner and Lindqvist, 1995). The ideal weight should be around $40 \mathrm{~g}$ (Pérez et al., 1997). According to our results, $P$. nicoleti would not be considered an attractive species for commercial aquaculture purposes because it would take four years to reach a size of approximately 43 $\mathrm{mm} \mathrm{CL}$ (which corresponds to $90 \mathrm{~mm}$ total length) and, even then, its total body weight would only be $15.3 \mathrm{~g}$ (Figs. 2, 3). These sizes and weights are reached by two, cold water species commonly cultured in Europe, Astacus astacus (Linnaeus, 1758) and Pacifastacus leniusculus (Dana, 1852), in only two years (Ackefors, 2000). Furthermore, two Chilean species with a certain degree of commercial potential, S. spinifrons and 


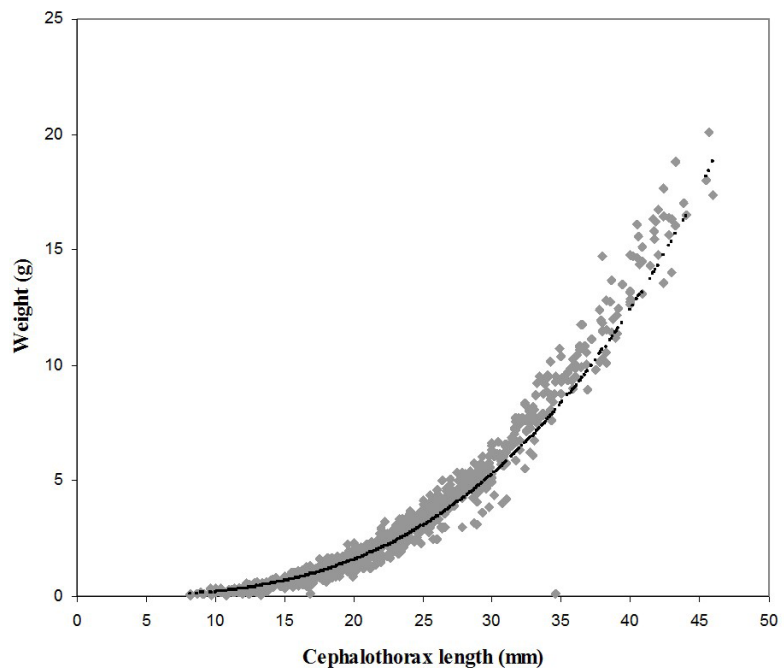

Figure 1. Size-weight relationship of the burrowing crayfish Parastacus nicoleti.

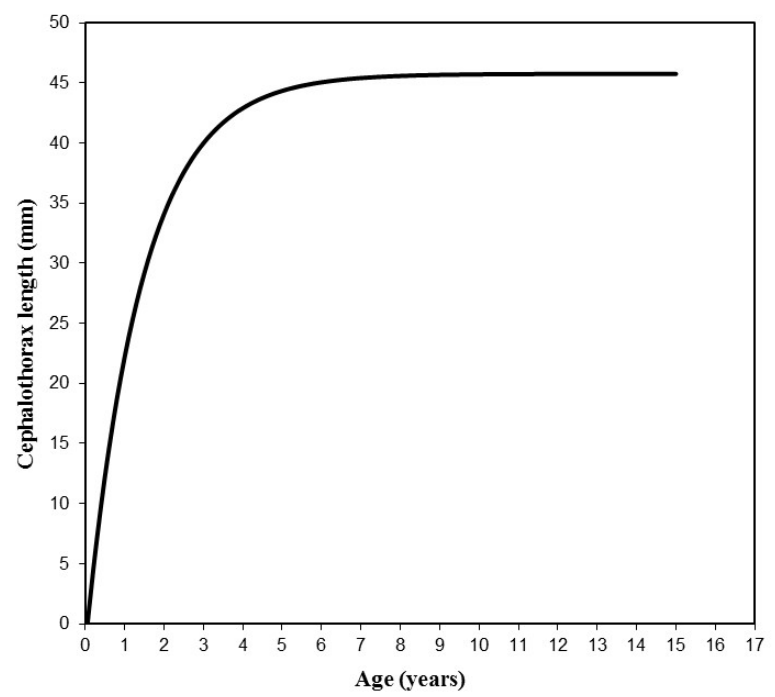

Figure 2. Length growth curve of the burrowing crayfish Parastacus nicoleti adjusted to the von Bertalanffy (1938) model.

Table 3. Individual growth parameters of some crayfish species.

\begin{tabular}{|c|c|c|c|c|c|c|}
\hline Family & Specie & $\mathrm{L} \infty(\mathrm{mm})$ & $\mathrm{Kmm} /$ year & Sex & Method & References \\
\hline \multirow[t]{9}{*}{ Astacidae } & $\mathrm{Aa}$ & 68.14 & 0.25 & Both & GHM & Cukerzis (1979) \\
\hline & Aa & 70.24 & 0.23 & Both & GHM & Cukerzis (1989) \\
\hline & Ap & 45.60 & 0.26 & Female & GHM & Pratten (1980) \\
\hline & & 54.20 & 0.21 & Male & GHM & \\
\hline & Ap & 87.40 & 0.33 & Female & GHM & Neveu (1996) \\
\hline & & 105.40 & 0.30 & Male & GHM & \\
\hline & & 201.40 & 0.47 & Male & GHM & $(2000)$ \\
\hline & At & 88.60 & 0.84 & Female & GHM & Streissl and Hödl (2002) \\
\hline & & 102.40 & 0.81 & Male & GHM & \\
\hline \multirow[t]{7}{*}{ Cambaridae } & $\mathrm{Pc}$ & 56.00 & 0.68 & Both & GM-MS & Anastacio and Marques (1995) \\
\hline & $\mathrm{Pc}$ & 62.00 & 0.23 & Both & GM-MS & Fidalgo et al. (2001) \\
\hline & & 63.30 & 0.66 & Male & GM-MS & \\
\hline & $\mathrm{Pc}$ & 65.50 & 0.69 & Female & GM-MS & Scalici and Gherardi (2007) \\
\hline & & 62.60 & 0.62 & Male & GM-MS & \\
\hline & Pc & 74.60 & 0.32 & Female & ELE & Scalici et al. (2010) \\
\hline & & 68.30 & 0.33 & Male & ELE & \\
\hline \multirow[t]{7}{*}{ Parastacidae } & $\mathrm{Cq}$ & 66.70 & 0.27 & Both & GM-MS & Beatty et al. (2005) \\
\hline & $\mathrm{Pb}$ & 42.89 & 0.002 & Both & GM, LR & Fries (1984) \\
\hline & $\mathrm{Pb}$ & 57.37 & 0.23 & Both & GM-MS & Fontoura and Buckup (1989) \\
\hline & $\mathrm{Pd}$ & 30.98 & 0.0026 & Both & GM, LR & Noro and Buckup (2009) \\
\hline & $\mathrm{Pp}$ & 59.50 & 0.334 & Both & ELE-MR & del Valle (2002) \\
\hline & $\mathrm{Pp}$ & 55.90 & 0.35 & Both & GHM-MR & Ibarra and Arana (2011) \\
\hline & $\mathrm{Pp}$ & 55.30 & 0.23 & Both & MPA-MS & Ibarra and Arana (2012) \\
\hline
\end{tabular}

Aa, Astacus astacus (Linnaeus, 1758); Ap, Austropotamobius pallipes (Lereboullet, 1858); At, Austropotamobius torremtium (Schrank, 1803); Pc, Procambarus clarkii (Girard, 1852); Cq, Cherax quinquecarinatus Gray, 1845; Pb, Parastacus brasiliensis (von Martens, 1869); Pd, Parastacus defossus Faxon, 1898; Pp, Parastacus pugnax (Poeppig, 1835); Pn, Parastacus nicoleti (Philippi, 1882); GM: Growth Model, MR: Mark-Recapture, LR: Laboratory rearing, MS: Monthly Samples, GHM: Gulland and Holt's (1959) method, ELE: ELEFAN , MPA: Modal progression analysis. 
P. pugnax are capable to reach $30 \mathrm{~g}$ weight in 3 years (Rudolph et al., 2010; Ibarra and Arana, 2011).

On comparing the growth parameters of the two Chilean species of Parastacus Huxley, 1879, it was verified that $P$. nicoleti reaches the asymptotic size in less time than P. pugnax. Furthermore, both species would reach $40 \mathrm{~mm}$ CL at approximately three years of age. However, from this size onwards, the increase in length of $P$. pugnax greatly exceeds that of $P$. nicolet $i$ (Fig. 4). Furthermore, P. pugnax would reach a weight of approximately $20 \mathrm{~g}$ (age $=2.5$ years) and of $40 \mathrm{~g}$ (age $=4$ years). According to our results, $P$. nicoleti is not capable to reach these weights during its life cycle (Fig. 5).

Our results suggest that $P$. nicoleti lives 4.32 years, similar to many other decapods (75.1\%) whose life span fluctuates between 1 and 10 years (Vogt, 2012). Nevertheless, P. nicoleti longevity is relatively short when compared to many species of Parastacidae that inhabit cold waters within the galleries and reach an average maximum age of 25.6 years (McLay and van den Brink, 2016). Thus, the short life span of P. nicoleti appears somewhat enigmatic, since this species is also a primary burrower that inhabits cold waters with an average temperature of $12.1^{\circ} \mathrm{C}$ (maximum of $17.5^{\circ} \mathrm{C}$; minimum of $8.5^{\circ} \mathrm{C}$ ) (Rudolph, 1997). On the other hand, this concurs with the longevity estimated for other species of Parastacus, such as P. defossus and $P$. brasilensis (Tab. 4). Like P. nicoleti, these species are not subject to extraction for commercial purposes and occupy similar habitats with comparable life styles, although at lower geographic latitudes (Fries, 1984; Noro and Buckup, 2009).

The freshwater crayfish (Astacoidea and Parastacoidea) are characterized by their direct development, with incubation of large eggs, rich in vitellus, hatching at juvenile stage 1 , parental care up to juvenile stage 2 and release in juvenile stage 3 (Vogt, 2013). Rudolph (1986) describes the external morphology of these three stages of early post embryonic development in P. nicoleti, and records their CL. Thus, the first juvenile measures on average $2.6 \mathrm{~mm}$, the second $3.2 \mathrm{~mm}$ and the third $3.8 \mathrm{~mm}$. If the growth model of this species is employed, estimated ages of the juveniles 1,2 and 3 would be approximately 51,58 and 65 days, respectively. These ages differ from the data provided by Rudolph (1986) who verified

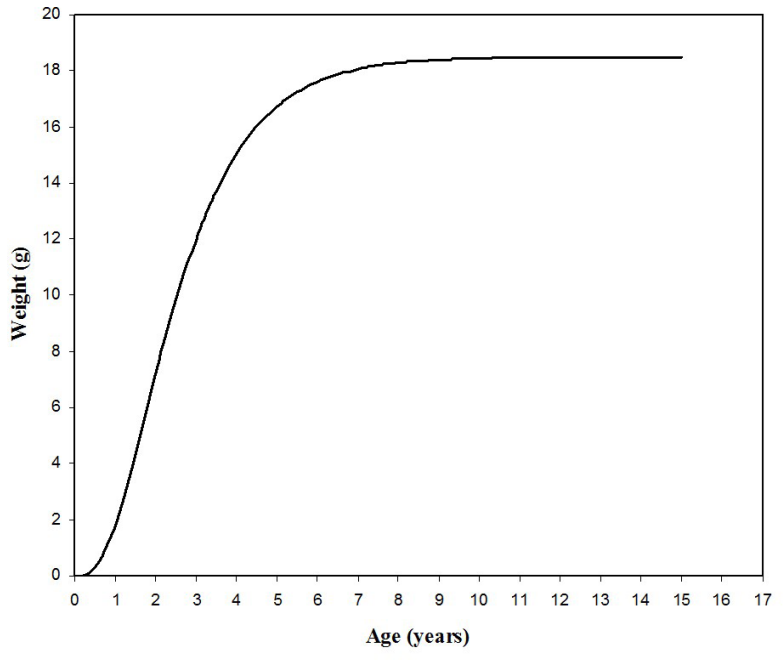

Figure 3. Weight growth curve of the burrowing crayfish Parastacus nicoleti adjusted to the von Bertalanffy (1938) model.

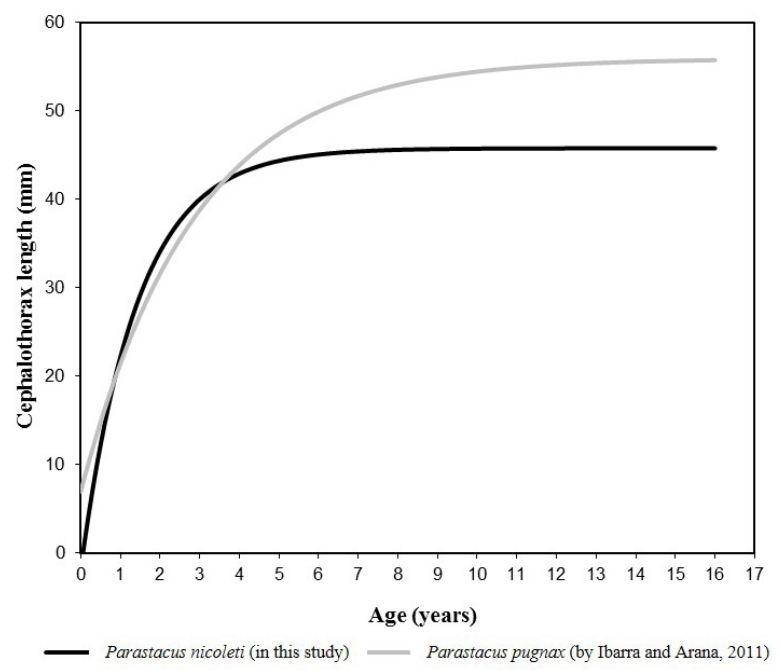

Figure 4. Comparison between length growth curves of Parastacus nicoleti and Parastacus pugnax adjusted to the von Bertalanffy (1938) model.

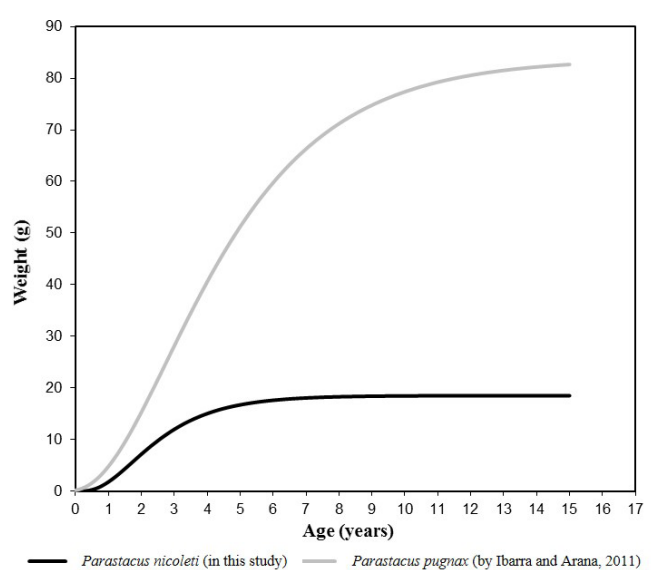

Figure 5. Comparison between weight growth curves of Parastacus nicoleti and Parastacus pugnax adjusted to the von Bertalanffy (1938) model. 
Table 4. Longevity of some crayfish species.

\begin{tabular}{lccl}
\hline Family & Species & Longevity (years) & References \\
\hline Astacidae & $\mathrm{Al}$ & 7.4 & $\begin{array}{l}\text { Deval et al. (2007) } \\
\text { Skurdal and Taugbol (2002) } \\
\text { Belchier et al. (1998) }\end{array}$ \\
& $\mathrm{Aa}$ & $>10$ & Reynolds et al. (1992) \\
Cambaridae & $\mathrm{Pl}$ & 16.7 & Walls (2009) \\
& $\mathrm{Pc}$ & & Kawai et al. (1992) \\
Cambaroididae & $\mathrm{Cs}$ & $1-1.5$ & Sheeby (1992) \\
& $\mathrm{Cj}$ & 1.5 & Noro and Buckup (2009) \\
& & 11.0 & In this study \\
Parastacidae & $\mathrm{Cqa}$ & & Fries (1984) \\
& $\mathrm{Pd}$ & 3.0 & Ibarra and Arana (2011) \\
& $\mathrm{Pn}$ & 3.3 & Ibarra and Arana (2012) \\
& $\mathrm{Pb}$ & 4.3 & Lukhaup and Pekny (2008) \\
\hline
\end{tabular}

Al, Astacus leptodactylus Eschscholtz, 1823; Pl, Pacifastacus leniusculus (Dana, 1852); Cs, Cambarellus shufeldtii (Faxon, 1884); Cj, Cambaroides japonicus (de Haan, 1841); Cqa, Cherax quadricarinatus (von Martens, 1868); Ag, Astacopsis gouldi Clark, 1936. Other abbreviations see Tab. 3.

that, at water temperatures of between 6.0 y $18.0^{\circ}$ $\mathrm{C}\left(\mathrm{x}=13.9^{\circ} \mathrm{C}\right)$, hatching occurs 65 days after laying, juvenile 2 emerges after 110 days and juvenile 3 at 134 days. These differences can probably be attributed to the effect of temperature. There is a lot of evidence supporting the belief that growth of crustaceans is related to water temperature (Kawai et al., 1997; Hartnoll, 2001; Reynolds, 2002; Mc Lay and van den Brink, 2016) and that there is a negative correlation between temperature and time taken to reach a given stage in the life cycle (Pinheiro and Taddei, 2005).

Finally, taking into account that P. nicoleti: 1 . is a burrowing species with a poorly developed pleon and, consequently has a low meat yield; 2 . presents low growth rates, we conclude that it would not be an attractive species for commercial aquaculture purposes.

\section{ACKNOWLEDGEMENTS}

We are grateful to the Vicerrectoría de Investigación y Postgrado of the Universidad de Los Lagos for financing the sampling process and to Susan Angus for translating the manuscript.

\section{References}

Ackefors, H.E.G. 2000. Freshwater crayfish farming technology in the 1990s: a European and global perspective. Fish and Fisheries, 1: 337-359.

Almerão, M.P.; Rudolph, E.; Souty-Grosset, C.; Crandall, K.; Buckup, L.; Amouret, J.; Verdi, A.; Santos, S. and Araujo, P.B. 2015. The native South American crayfishes (Crustacea,
Parastacidae): state of knowledge and conservation status. Aquatic Conservation: Marine and Freshwater Ecosystems, 25: 288-301.

Anastacio, P. and Marques, J. 1995. Population biology and production of the red swamp crayfish Procambarus clarkii (Girard, 1852) in the lower Mondego river valley, Portugal. Journal of Crustacean Biology, 15: 156-168.

Arreguín, F.; Sánchez, J.A. and Defeo, O. 1991. Análisis del crecimiento de la almeja amarilla (Mesodesma mactroides) de la costa uruguaya en base a datos de composición por longitudes. Frente Marítimo, 9: 75-81.

Bahamonde, N.; Carvacho, A.; Jara, C.; López, M.; Ponce, F.; Retamal, M. A. and Rudolph, E. 1998. Categorías de conservación de decápodos nativos de aguas continentales de Chile. Boletín del Museo Nacional de Historia Natural, 47: 91-100.

Beatty, S.J.; Morgan, D.L. and Gill, H. S. 2005. Life history and reproductive biology of the gilgie Cherax quinquecarinatus, a freshwater crayfish endemic to southwestern Australia. Journal of Crustacean Biology, 25: 251-262.

Belchier, M.; Edsman, L.; Sheehy, M.R.J. and Shelton, P.M.J. 1998. Estimating age and growth in long-lived temperate crayfish using lipofucsin. Journal of Freshwater Biology, 39: 439-446.

Bhattacharya, C. G. 1967. A simple method of resolution of a distribution into Gaussian components. Biometrics, 23: 115-135.

Bocic, V.; Rudolph, E. and López, D. 1988. Biología reproductiva y dinámica poblacional del camarón de río, Samastacus spinifrons (Philippi, 1882) (Decapoda, Parastacidae). Boletín de la Sociedad de Biología de Concepción, Chile, 59: 9-21.

Buckup, L. 2010. Parastacus nicoleti. In: IUCN 2013. IUCN Red list of threatened species. Version 2013.2.

Chiesa, S.; Scalici, M. and Gibertini, G. 2006. Occurrence of allochthonous freshwater crayfishes in Latium (Central Italy). Bulletin Français Pêche et Pisciculture, 380-381: 883-902.

Cukerzis, J.M. 1979. On acclimatation of Pacifastacus leniusculus Dana in an isolated Lake. Freshwater Crayfish, 4: 445-450. 
Cukerzis, J.M. 1989. Freshwater Crayfish. Monograph, Vilnius Mokslas Publishers, 143p.

Csirke, J. 1980. Recruitment in the Peruvian anchovy and its dependence on the adult population. Rapports et ProcèsVerbaux des Réunions du Conseil Permanent International pour l' Exploration de la Mer, 177: 307-313.

del Valle, E. 2002. Dinámica poblacional y ecología del camarón de vega Parastacus pugnax. Universidad Católica del Norte, Coquimbo, Chile, Tesis. 52 p. [Unpublished].

Deval, M.C.; Bök, T.; Ateş, C. and Tosunoğlu, Z. 2007. Length based estimates of growth parameters, mortality rates, and recruitment of Astacus leptodactylus (Eschscholtz, 1823) (Decapoda, Astacidae) in unexploited inland waters of the northern Marmara region, European Turkey. Crustaceana, 80: 655-665.

Fidalgo, M.; Carvalho, P. and Santos, P. 2001. Population dynamics of the red swamp crayfish, Procambarus clarkii (Girard, 1852) from the Aveiro Region, Portugal (Decapoda, Cambaridae). Crustaceana, 74: 369-375.

Fontoura, N.F. and Buckup, L. 1989. O crescimento do Parastacus brasiliensis (von Martens, 1869) (Crustacea, Decapoda, Parastacidae). Revista Brasileira de Biologia, 49: 897-909.

Fries, B.G. 1984. Observações sobre o lasgostim de água doce Parastacus brasiliensis (von Martens, 1869) em condições de cultivo experimental em laboratório (Crustacea, Decapoda, Parastacidae). Revista Brasileira de Biologia, 44: 409-416.

Gayanilo, F. C. Jr.; Sparre, P. and Pauly, D. 2005. FAO-ICLARM Stock Assessment Tools II (FiSAT II). Revised version. User's guide. FAO Computerized Information Series (Fisheries), 8: $1-168$.

Gulland, J.A. and Holt, S.J. 1959. Estimation of growth parameters for data at unequal time intervals. Journal $d u$ Conseil International pour l'Explorations de la Mer, 25: 47-49.

Hartnoll, R.G. 1982. Growth. p. 111-196. In: D.E. Bliss and L.G. Abele (eds), The Biology of Crustacea. Embriology, Morphology, and Genetic, Vol. 2. New York, Academic Press.

Hartnoll, R.G. 2001. Growth in Crustacea - twenty years on. Hydrobiologia, 449: 111-122.

Huner, J.V. and Lindqvist, O.V. 1995. Physiological adaptations of freshwater crayfishes that permit successful aquacultural enterprises. American Zoology, 35: 12-19.

Ibarra, M. and Arana, P. 2011. Crecimiento del camarón excavador Parastacus pugnax (Poeppig, 1835) determinado mediante técnica de marcaje. Latin American Journal of Aquatic Research, 39: 378-384.

Ibarra, M. and Arana, P. 2012. Biological parameters of the burrowing crayfish, Parastacus pugnax (Poeppig, 1835), in Tiuquilemu, Biobío Region, Chile. Latin American Journal of Aquatic Research, 40: 418-427.

IUCN - International Union for Conservation of Nature. 2012. IUCN Red List Categories and Criteria: Version 3.1, Second edition. IUCN, Gland, Switzerland and Cambridge, 32p.

Kawai, T.; Hamano, T. and Matsuura, S. 1997. Survival and growth of the Japanese crayfish Cambaroides japonicus in a small stream in Hokkaido. Bulletin of Marine Science, 61: 147-157.

Kilian, E. 1959. La construcción de los tubos habitacionales del Parastacus nicoleti (Philippi, 1882). Facultad de Estudios Generales, Universidad Austral de Chile, 1:1-7.
Lobão, V.L.; Musto, M.R.Z.N.; Rojas, N.E.T.; Lance, M. and Magalhães, M.F.S. 1987. Estudo populacional de Macrobrachium iheringi (Ortmann, 1897) (Decapoda, Palaemonidae) do Rio Buava - SP. Boletin do Instituto de Pesca, São Paulo, 13: 37-43.

Lukhaup, C. and Pekny, R. 2008. Süßwasserkrebse aus aller Welt, 2. Auflage. Dähne Verlag, Ettlingen, 291p.

McLay, C.L. and van den Brink, A.M. 2016. Crayfish growth and reproduction. p. 62-116. In: M. Longshaw and P. Stebbing (eds), Biology and Ecology of Crayfish. Boca Raton, CRC Press.

MMA - Ministerio del Medio Ambiente. 2013. Parastacus nicoleti. Available at http://www.mma.gob.cl/clasificacionespecies/ fichas 10 proceso/fichas_10_pac/Parastacus nicoletii_10RCE_01_PAC.pdf. Accessed on 8 June 2016.

Neveu, A. 1996. Caractéristique démographiques de stocks résiduels de l' écrevisse a pattes blanches, Austropotamobius pallipes (Astacidae), en Normandie. Cybium, 20: 75-93.

Noro, C.K. and Buckup, L. 2009. O crescimento do Parastacus defossus (Crustacea: Decapoda: Parastacidae). Zoologia, 26: 54-60.

Pinheiro, M.A.A. and Taddei, F.G. 2005. Crescimento do caranguejo de água doce, Dilocarcinus pagei Stimpson (Crustacea, Brachyura, Trichodactylidae). Revista Brasileira de Zoologia, 22: 522-528.

Pratten, D.J. 1980. Growth in the crayfish Austropotamobius pallipes (Crustacea: Astacidae). Freshwater Biology, 10: 401-412.

Pérez, J.R.; Celada, J.D.; Carral, J.M.; Saez-Royuela, M.; Muñoz, C and Sierra, A. 1997. Métodos básicos de cría de astácidos en Europa. Investigación Agraria: Producción y Sanidad Animales, 12: 87-96.

Rallo, A. and García-Arberas, L. 2000. Population structure and dynamics and habitat of the native crayfish Austropotamobius pallipes in a pond; a case study in Basque Country (Northern Iberian Peninsula). Bulletin Français Pêche et Pisciculture, 356: 5-16.

Reynolds, J.D. 2002. Growth and Reproduction. p.152-191. In: D.M. Holdich (ed), Biology of Freshwater Crayfish. Oxford, Blackwell Science.

Reynolds, J.D.; Celada, J.D.; Carral, J.M. and Matthews, M.A. 1992. Reproduction of astacid crayfish in captivity-current developments and implications for culture, with special reference to Ireland and Spain. Invertebrate, Reproduction and Development, 22: 253-266.

Ribeiro, F.B. and Araujo, P.B. 2017. Designation of a neotype for Parastacus nicoleti (Philippi, 1882) (Crustacea: Decapoda: Parastacidae). Zootaxa, 4338: 393-400.

Ricker, W.E. 1975. Computation and interpretation of biological statistics of fish populations. Bulletin of the Fisheries Research Board of Canada, 191: 1-382.

Rodriguez, L. and Bahamonde, R. 1986. Estimación del crecimiento y mortalidad natural en Munida subrugosa del Estrecho de Magallanes. Investigación Pesquera, 33: 25-32.

Rudolph, E.H. 1995. Partial protandric hermaphroditism in the burrowing crayfish Parastacus nicoleti (Philippi, 1882) (Decapoda: Parastacidae). Journal of Crustacean Biology, 15: 720-732.

Rudolph, E.H. 1997. Aspectos fisicoquímicos del hábitat y morfología de las galerías del camarón excavador Parastacus 
nicoleti (Philippi, 1882) (Decapoda, Parastacidae) en el sur de Chile. Gayana Zoología, 61: 97-108.

Rudolph, E.H. 2010. Sobre la distribución geográfica de las especies chilenas de Parastacidae (Crustacea: Decapoda: Astacidea). Boletín de Biodiversidad de Chile, 3: 32-46.

Rudolph, E.H. 2013. A checklist of the Chilean Parastacidae (Decapoda, Astacidea). Crustaceana, 86: 1468-1510.

Rudolph, E H. and Almerão M.P. 2015. The native South American crayfish (Decapoda: Parastacidae).p. 464-484. In: T. Kawai, Z. Faulkes and G. Scholtz (eds), Freshwater crayfish: a global overview. Boca Raton, CRC Press.

Rudolph, E.H. and Crandall, K.A. 2005. A new species of burrowing crayfish, Virilastacus rucapihuelensis (Crustacea: Decapoda: Parastacidae), from southern Chile. Proceedings of the Biological Society of Washington, 118: 765-776.

Rudolph, E.H. and Crandall, K.A. 2007. A new species of burrowing crayfish Virilastacus retamali (Decapoda, Parastacidae) from the southern Chile peatland. Journal of Crustacean Biology, 27: 502-512.

Rudolph, E.; Retamal, F. and Martínez, A. 2010. The culture of freshwater crayfish Samastacus spinifrons: a new alternative for the diversification of the Chilean aquaculture? Latin American Journal of Aquatic Research, 38: 254-264.

Rudolph, E. and Zapata, L. 1986. Desarrollo embrionario y postlarval del camarón de las vegas Parastacus nicoleti (Philippi, 1882) en condiciones de laboratorio. Biota, 2: 37-50.

Scalici, M.; Chiesa, S.; Scuderi, S.; Celauro, D. and Gibertini, G. 2009. Population structure and dynamics of Procambarus clarkii (Girard, 1852) in a Mediterraean brackish wetland (Central Italy). Biological Invasions, 12: 1415-1425.

Scalici, M. and Gherardi, F. 2007. Structure and dynamics of an invasive population of the red swamp crayfish (Procambarus clarkii) in a Mediterranean wetland. Hydrobiologia, 583: 309-319.

Sheehy, M.R.J. 1992. Lipofucsin age-pigment accumulation in the brains of ageing field -and laboratory-reared crayfish Cherax quadricarinatus (von Martens) (Decapoda: Parastacidae). Journal of Experimental Marine Biology and Ecology, 161: 79-89.

Skurdal, J. and Taugbol, T. 2002. Astacus. p. 467-510. In: D.M. Holdich (ed). Biology of Freshwater Crayfish. Oxford, Blackwell Science.

Streissl, F. and Hödl, W. 2002. Growth, morphometrics, size at maturity, sexual dimorphism and condition index of Austropotamobius torrentium Schrank. Hydrobiologia, 477: 201-208.

Taylor, C. 1958. Cod growth and temperature. Journal du Conseil International pour l'Explorations de la Mer, 23: 366-370.

Vogt, G. 2012. Ageing and longevity in the Decapoda (Crustacea): A review. Zoologischer Anzeiger, 251: 1-25.

Vogt, G. 2013. Abbreviation of larval development and extension of brood care as key features of the evolution of freshwater Decapoda. Biological Reviews, 88: 81-116.

von Bertalanffy, L. 1938. A quantitative theory of organic growth. Human Biology, 10: 181-243.

Walls, J.G. 2009. Crawfishes of Louisiana. Lousianna State University Press, Baton Rouge, 240p.

Wright-López, H.; Holguin-Quiñones, O.; Arreguín-Sánchez, F. and Roque-Villada, I. 2009. Crecimiento y mortalidad de la concha nácar Pteriasterna en bancos silvestres de Baja California Sur, México. Revista de Biología Tropical, 57: 659-670. 